\title{
Diacronie
}

Studi di Storia Contemporanea

$N^{\circ} 18,2 \mid 2014$

Le esposizioni: propaganda e costruzione identitaria

\section{La gran exposición anticomunista del Tercer Reich: Das Sowjetparadies (1942)}

Antonio César Moreno Cantano y Misael Arturo López Zapico

\section{(2) OpenEdition}

Journals

\section{Edición electrónica}

URL: http://journals.openedition.org/diacronie/1532

DOI: $10.4000 /$ diacronie. 1532

ISSN: 2038-0925

\section{Editor}

Association culturelle Diacronie

\section{Referencia electrónica}

Antonio César Moreno Cantano y Misael Arturo López Zapico, « La gran exposición anticomunista del Tercer Reich: Das Sowjetparadies (1942) », Diacronie [En línea], № 18, 2 | 2014, documento 16, Puesto en línea el 01 junio 2014, consultado el 30 abril 2019. URL : http://journals.openedition.org/ diacronie/1532; DOI : 10.4000/diacronie.1532 


\section{Diacronie}

16/

\section{La gran exposición anticomunista del Tercer Reich: Das Sowjetparadies (1942)}

Antonio César MORENO CANTANO, Misael Arturo LÓPEZ ZAPICO *

Aunque su origen se pueda rastrear ya desde tiempos pretéritos la propaganda de atrocidades cobró una especial relevancia como eje articulador de los discursos orientados a justificar la extrema violencia ejercida hacia el "otro" durante los grandes conflictos del siglo XX. Pocos Estados fueron tan hábiles como el régimen nazi para utilizar a su favor la capacidad del Arte para vertebrar el proceso de socialización violenta de su ciudadanía. El poder de la imagen para proyectar una visión degradada del enemigo que, a su vez, reforzaba la validez de los argumentos de su emisor queda perfectamente de manifiesto en la exposición Das Sowjetparadies celebrada en Berlín en 1942. En este artículo analizamos su contenido y reflexionamos sobre la importancia de este tipo de acciones para propagar un discurso netamente anticomunista y antisemita.

\section{Presentación: propaganda al servicio del odio}

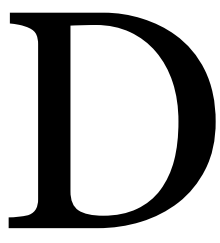

esde hace siglos ha sido una constante en el ser humano la apelación a los sentimientos y prejuicios tradicionales para mover a las masas en una dirección determinada. Un recurso muy eficaz en esta maniobra ha sido la Propaganda de Atrocidades (Atrocity Propaganda), entendida la misma 
como la denuncia pública (si se recurre al principio de la exageración y la desfiguración mucho mejor) de los "crímenes" del adversario y la repulsa de sus cualidades". Uno de los primeros ejemplos de la importancia de este tipo de discursos se retrotrae a la Edad Media. El 27 de noviembre de 1095, el papa Urbano II, en el Concilio de ClermontFerrand, ante miles de francos y bajo el pretexto de recuperar Jerusalén, esgrimió toda una serie de acusaciones y reproches contra el "infiel":

Destruyen los altares, después de haberlos contaminado con su inmundicia. Circuncidan a los cristianos y la sangre de la circuncisión es rociada sobre el altar o las pilas bautismales. Les gusta matar a otros abriéndoles el abdomen, sacándoles una extremidad del intestino que luego atan a un poste².

¿Por qué traemos a colación estas palabras? Además de ilustrar con ellas un cuadro primigenio de la utilización del odio para enervar a los creyentes, hallamos -sin olvidar las grandes diferencias que existen- paralelismos evidentes con el discurso elaborado por el nacionalsocialismo alemán desde sus principios. Tanto Urbano II como Hitler (ya en Mein Kampf) hablaban de una "raza elegida" (los francos para el primero y los arios para el segundo) que debía hacer frente a un enemigo diabólico (los musulmanes/bolchevismo-judaísmo ruso) para garantizar la supervivencia de la civilización occidental. Casi nueve centurias después del inicio de la Primera Cruzada, el Tercer Reich hacía un llamamiento a una nueva Cruzada (término muy presente en la Guerra Civil española por parte del bando franquista) de las naciones europeas, en esta ocasión contra la URSS. A raíz de la “Operación Barbarroja” (calificada por el mariscal Antonescu como una guerra santa3) se desplegó por toda la Europa del Eje una auténtica corriente de odio contra el vecino ruso. Expresado el mismo de multitud de formas, uno de los aspectos más llamativos y atractivos para las masas fue el que se plasmó a través de grandes exposiciones internacionales, que recurriendo al arte (pabellones fotográficos, murales, carteles, esculturas, pinturas) y la propaganda crearon un prototipo del enemigo totalmente despreciable para los ciudadanos germanos, franceses o españoles.

Como se argumentó desde el ámbito de la Psicología (por ejemplo, Mac Dougall en su obra The Ground Mind, 1920), ya a principios del siglo XX, uno de los fenómenos

\footnotetext{
1 Sobre este tema nos remitimos a GARCÍA FERNÁNDEZ, Hugo, «Seis y media docena: Propaganda de atrocidades y opinión británica durante la Guerra Civil española», in Hispania. Revista Española de Historia, LXVII, 226, 2/2007, pp. 671-692.

2 HEERS, Jacques, La Primera Cruzada, Barcelona, Editorial Andrés Bello, 1995, pp. 77-85.

3 KERSHAW, Ian, Hitler, 1936-1945, Barcelona, Ediciones Península, 2000, p. 380.
} 
más singulares e importantes de la formación de las masas consistía en la exaltación e intensificación de la emotividad de los individuos que la integran. Conscientes de estas ideas, todas estas exposiciones estaban proyectadas a una colectividad que se sobreentendía - máxime en un contexto de contienda mundial - como excitable, impulsiva, apasionada, versátil, inconsecuente, indecisa, accesible a las pasiones violentas y a los sentimientos elementales, fácil de sugestionar4. En los últimos años se ha orientado el estudio de la cultura visual bélica atendiendo a todos los condicionantes recién esbozados. Paradigmático e innovador en este sentido es el trabajo colectivo de Berthier y Sánchez Biosca, cuyo eje de análisis se basaba en el concepto de miedo5. El instinto más primario - y en intensa relación con este- presente en todo tipo de eventos propagandísticos fue el odio ${ }^{6}$. El miedo es una emoción aversiva primaria que experimenta una persona o grupo ante situaciones que considera una amenaza o riesgo, y que pueden ser creadas o exacerbadas por sectores que se encuentran en el poder con el fin de justificar y legitimar sus acciones7. De este sentimiento se deriva el odio, formando ambos un clima emocional negativo que predispone a los individuos a desarrollar o aceptar comportamientos hostiles hacia un grupo objetivo, debido a la identificación que se hace de ellos como una amenaza. Para eso es necesario atribuirle al otro, al enemigo, un conglomerado de atributos peyorativos, que crearan en los sujetos un juicio de valor igualmente negativo ${ }^{8}$.

Este tipo de sentimientos (ira, odio, miedo, desconfianza...), impulsados por la propaganda de guerra, encajan en lo que la ciencia histórica ha bautizado en los últimos años como Historia de las emociones, cuyos principales impulsores han sido Peter Burke, Barbara H. Rosenwein o William M. Reddy 9 . La nueva historia cultural defiende la relevancia social de los sentimientos como matrices que sostienen los comportamientos $^{10}$. Los individuos de una época - en este caso de enfrentamiento

\footnotetext{
4 Véase, FREUD, Sigmund, Psicología de las masas, Madrid, Alianza Editorial, 1991, pp. 22-25. 5 BERTHIER, Nancy, SÁNCHEZ-BIOSCA, Vicente, Retóricas del miedo. Imágenes de la Guerra Civil española, Madrid, Collection de la Casa de Velázquez (129), 2012.

6 STERNBERG, Robert, STERNBERG, Karin, The Nature of Hate, Cambridge, Cambridge University Press, 2008, pp. 59-62.

7 ARAYA, María del Carmen, «El miedo acecha y el consumo seduce. Dos caras del modelo psicológico dominante en tiempos de globalización», in Universitas Humanistica, 67, 2008, pp. 54-79, p. 58.

8 AMOSSY, Ruth, HERSCHBERG, Anne, Estereotipos y Clichés, Buenos Aires, Eudeba, 2001, pp. 38-40.

9 Un análisis de los mismos en ZARAGOZA BERNAL, Juan Manuel, «Historia de las emociones: una corriente historiográfica en expansión», in Asclepio, 65, 1/2013. URL:

< http://asclepio.revistas.csic.es/index.php/asclepio/article/view/547/572 >[consultado el 5 de junio 2014].

10 MEDINA DOMÉNECH, Rosa María, «Sentir la historia. Propuestas para una agenda de investigación feminista en la historia de las emociones», in Arenal, 19, 1/2012, pp. 161-199.
} 
fratricida - adquieren su racionalidad a través del aprendizaje sistemático de una serie de prácticas emocionales, que nos inclinamos a considerar como producto de una construcción social, del resultado de un adoctrinamiento que busca una respuesta determinada en el individuo y que se solapa con sus propias experiencias vitales.

A partir de 1936, con la gradual radicalización de la política nazi (mayor agresividad en política exterior, incremento del Estado de terror, reorganización del Gobierno y del Ejército), el propio Goebbels abandonó sus concomitancias con el modernismo y pasó a ser uno de sus más efectivos hostigadores. La celebración de los Juegos Olímpicos en Berlín supuso un paréntesis de paz y tranquilidad dentro de la, cada vez más excluyente, política cultural y racial nazi. Con su finalización, toda la ira del Reich se desató y comenzaron a organizarse, por todo el país, numerosas exposiciones de propaganda contra el bolchevismo, el judaísmo (interpretados como un mismo cuerpo), y el arte modernista, al que se veía como un pernicioso producto de los anteriores. En el mitin del NSDAP de septiembre de 1936, Hitler dijo que el objetivo del bolchevismo, creado y dirigido por los judíos, era "exterminar" y destruir la cultura de los Estados europeos. Una vez cumplido este objetivo, "sería seguido por el establecimiento de un Judaísmo internacional que dominaría Europa" ${ }^{11}$. Atendiendo a estas premisas se desplegaron por todo el país una serie de eventos propagandísticos cuya finalidad principal era "recordar" a la población los defectos y peligros que entrañaba para la sociedad germana el judío, inexorablemente ligado al comunismo internacional. Mediante paneles, carteles, fotomontajes y otros elementos visuales, estas exposiciones tendrán como principal meta fomentar el odio hacia estos grupos y lograr la adhesión a las tesis nazis recurriendo para ello a un discurso fundamentado en el miedo. Das Sowjetparadies fue un claro ejemplo de ello. Previamente, en la Francia de Vichy, la exposición Le Bolchevisme contre l'Europe había señalado el camino ${ }^{12}$.

\section{Generalidades teóricas sobre Arte y Violencia en el Tercer Reich}

En el ya clásico trabajo de Gellatelly sobre los respaldos sociales del nazismo se podía leer - muy acertadamente - que «Hitler pretendía crear una dictadura, pero

\footnotetext{
${ }^{11}$ HERF, Jeffrey, The Jewish Enemy. Nazi propaganda during World War II and the Holocaust, Cambridge (Mass.), Harvard University Press, 2006, pp. 42-43.

12 PESCHANSKI, Denis, La propaganda sous Vichy, 1940-1944, París, Bibliothèque de Documentation Internationale Contemporaine (BDIC), 1990, pp. 96-109; ROSSIGNOL, Dominique, Histoire de la propagande en France de 1940 à 1944. L'utopie Pétain, París, Presses Universitaries de France, 1991, pp. 275-279.
} 
también quería el apoyo del pueblo»13. Para lograr la plena adhesión del ciudadano alemán a su programa ideológico se sirvió, desde un primer momento, de una serie de conceptos básicos, cargados de sentimentalismo, para despertar el interés por su causa. Es lo que algunos autores han calificado como el mito nazi, a saber: el sentido de raza y la teoría del Lebensraum o espacio vital, al que supuestamente tenía derecho el pueblo germano para poder configurarse como Estado de pleno derecho y que se resumía en la frase nazi: "sangre y suelo" (Blut und Boden)14. Ambas ideas, que tienen un fuerte componente violento (las mismas adquieren pleno fundamento mediante la confrontación con otros grupos raciales y comunidades étnicas), fueron desarrolladas desde época muy temprana en títulos como El mito del siglo $X X$ (1930), de Alfred Rosenberg, y Mein Kampf (1927), de Adolf Hitler. En el primero de ellos ya se señalaba al judío como el "anti tipo", una figura abstracta, sin forma ni alma, la contradicción del germano15. Por su parte, el líder nazi advertía que la constitución de un nuevo Reich solo encontraría razón de ser «mediante la adquisición de nuevos territorios en Europa» ${ }^{16}$. Y apuntaba directamente hacia el Este, a Rusia, en manos - según su parecer - del judaísmo internacional. Tenemos ya ante nuestros ojos la conexión judeo bolchevique como responsable de los males pasados del pueblo alemán y como freno a su posterior evolución:

Todo lo que por doquier leemos en el mundo en contra de Alemania procede de inspiración judía... Saltan a la vista los razonamientos del proceder judío. La bolchevización de Alemania ${ }^{17}$.

Este pensamiento, que ni mucho menos era fruto de una creación original (tenía sus orígenes en el racismo y pangermanismo del conde de Gobineau - Ensayo sobre la desigualdad - y del escritor Houston Stewart Chamberlain - Los fundamentos del siglo $\left.X I X^{18}\right)$, partía de un eje violento que tendrá su plasmación en la configuración del Tercer Reich: desde el Derecho a la Educación, pasando por las manifestaciones artísticas.

${ }^{13}$ GELLATELLY, Robert, No sólo Hitler. La Alemania nazi entre la coacción y el consenso, Barcelona, Crítica, 2002, p. 13.

${ }_{14}$ LACOUE-LABARTHE, Philippe y NANCY, Jean-Luc, El mito nazi, Barcelona, Anthropos Editorial, 2002. Véase especialmente, pp. 38-51.

15 Ibidem, p. 42.

${ }^{16}$ HITLER, Adolf, Mi lucha, Barcelona, Ediciones Ojeda, 1999, p. 324. Sobre la teoría del espacio vital véase, SMITH, Woodruff D., The ideological origins of nazi imperialism, Oxford, Oxford University Press, 1989.

${ }^{17}$ HITLER, Adolf, Mi lucha, cit., p. 331.

${ }^{18}$ Sobre este tema véase, HUTTON, Christoph, Race and the Third Reich: Linguistics, Racial Anthropology and Genetics in the Dialectic of Volk, Cambridge, Polity Press, 2005. 
El arte contemporáneo se ha caracterizado desde sus principios por una fuerte carga de violencia visual. Como remarcaba el filósofo francés Henri Bergson, «el rasgo distintivo del arte es que produce un choque»19. Sin embargo, la simple repetición de imágenes de violencia no cumple su finalidad si no va acompañada de otra clave importante: exige la aceptación y asimilación de una ideología que justifique o legitime el contenido de tales representaciones ${ }^{20}$. Richard Rhodes fue uno de los primeros historiadores que buscó una respuesta a la violencia presente en el Tercer Reich desde el campo de la criminología ${ }^{21}$. Para ello se inspiró en la revolucionaria teoría de Lonnie Athens, conocida como «Proceso de socialización violenta», que se dividía en cuatro etapas secuenciales: cada una de ellas debía ser completamente experimentada antes que el sujeto avanzase hacia la siguiente, un proceso que podía ocurrir como un cataclismo en un corto periodo de tiempo, o a través de un largo periodo de años. Estas fases eran: 1) Brutalización; 2) Beligerancia; 3) Actuación Violenta; 4) Virulencia. Aunque esta teoría fue elaborada para dar una explicación al comportamiento violento de los funcionarios de los cuerpos de seguridad del Estado nazi así como del estamento militar, algunas de sus conclusiones, sobre todo las de la primera fase, pueden extrapolarse al mensaje y mecanismos empleados por la maquinaria propagandística del Tercer Reich para despertar el odio / violencia que se encontraba en la base de futuras acciones deleznables de la sociedad alemana. En la fase conocida como brutalización se combinaban tres experiencias significativas: la subyugación violenta, la aterrorización personal y - la que más nos interesa - el adoctrinamiento violento. Sustituyendo al "noviciado" - al que constantemente nombra Athens - por el ciudadano común, en los trabajos del citado criminólogo se nos explicaba que este adoctrinamiento era ejercido, en primera instancia, por los grupos primarios: padre, madre, tío, abuelo, hermano. Las experiencias de violencia que estas personas han experimentado a lo largo de su vida son narradas ante el sujeto de manera constante, mostrándole que el mundo está poblado por seres repugnantes ante los que había que reaccionar de manera conveniente. El objetivo no es promover el ataque contra el contrario - al menos en esta fase -, sino evitar que el individuo se convirtiese en un ser pasivo, que fuese capaz de reaccionar ante aquello que amenazaba su integridad (no

19 Véase, LÓPEZ RODRÍGUEZ, Raquel, «Arte contemporáneo y violencia», in I Jornadas de Estudio, Reflexión y opinión sobre Violencia, Sevilla, Universidad de Sevilla, 2005, p. 231.

${ }^{20}$ BOZAL FERNANDEZ, Valeriano, Introducción, in ID. et al., Ejercicios de la violencia en el arte contemporáneo, Pamplona, Cátedra Jorge Oteiza \& Universidad Pública de Navarra, 2006, pp. 29-30.

${ }_{21}$ RHODES, Richard, Amos de la muerte. Los SS Einsatzgruppen y el origen del Holocausto, Barcelona, Seix Barral, 2003, pp. 44-57. 
primordialmente física sino cultural e ideológica) ${ }^{22}$. Este "adoctrinador", que nosotros equipararemos con el Ministerio de Propaganda o las diversas instituciones culturales y educativas del Reich, utilizaba diferentes técnicas para inocular esta violencia. Una de ellas es la vanagloriación, lo que implica posicionarse frente a un opuesto al que se considera diabólico. Recordemos los continuas apelaciones a la "puñalada por la espalda" (Dolchstosslegende) de la propaganda nazi, en concreto a determinados "elementos" (judíos y partidos de izquierda) en la derrota alemana en la Primera Guerra Mundial. Bajo esta temática se elaboraron numerosos panfletos e imágenes que incidían en la "cobardía" y oportunismo del pueblo judío en los momentos de mayor debilidad germana en la contienda bélica.
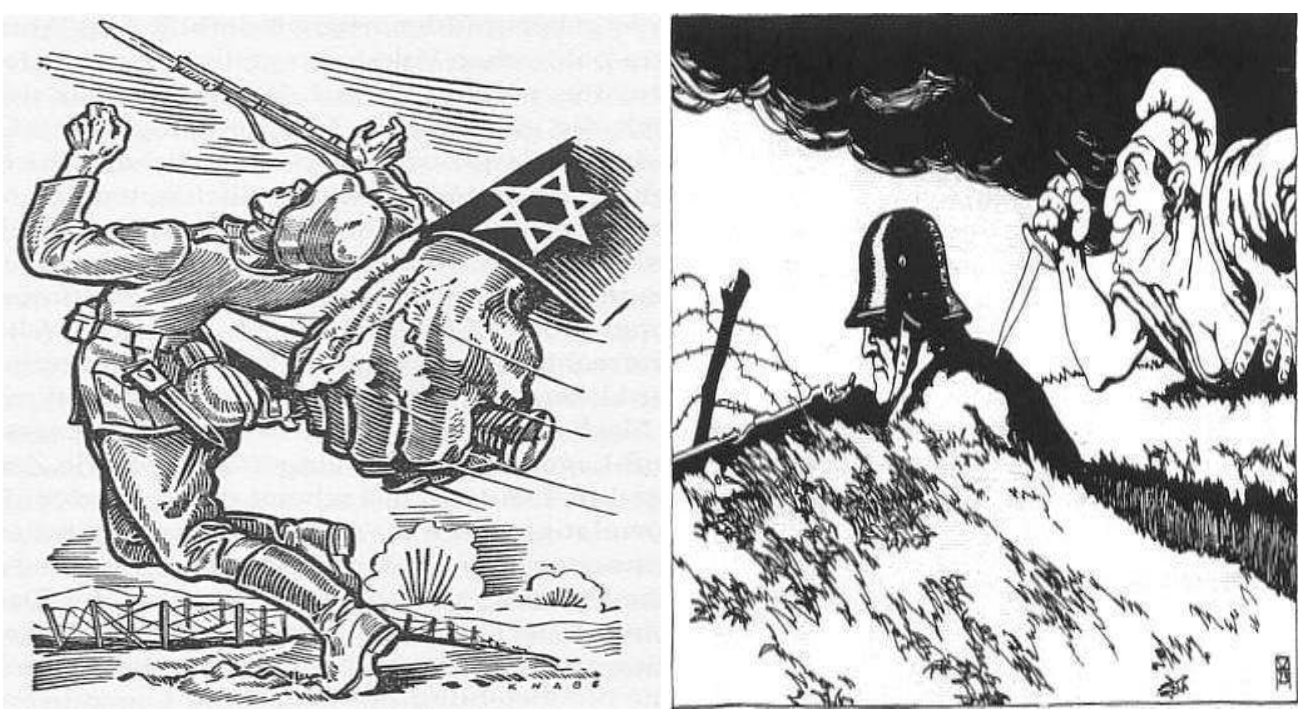

Figg. 1, 2. Diferentes imágenes que incidían en la "traición” judía durante la Primera Guerra Mundial.

(Fuente: Archivo personal del autor)

El "educador" estatal utilizó de multitud de imágenes, películas, libros, folletos... cargados de una gran virulencia y odio que proporcionaron el caldo de cultivo para iniciativas más violentas y brutales contra los diferentes “enemigos" del pueblo alemán.

En esta primera categoría de la violencia y el odio (la brutalización y su adoctrinamiento) se ubicó el arte y cultura nazi. Los propagandistas, artistas, entre otros gremios, con sus escritos, pinceles o lápices fueron uno de los eslabones de este embrutecimiento de la sociedad. Con sus producciones contribuyeron a exacerbar una serie de prejuicios y obsesiones contra los judíos y los comunistas, cumpliendo al pie de

${ }^{22}$ ATHENS, Lonnie H., The creation of dangerous violent criminals, Urbana and Chicago, University of Illinois Press, 1992, pp. 46-49; ATHENS, Lonnie H., ULMER, Jeffrey, Violent Acts and Violentization: assessing, applying and developing Lonnie Athen's Theories, Oxford, Elsevier Science, 2003. Véase en especial pp. 1-42. 
la letra las indicaciones de los organismos estatales responsables de la cultura y el adoctrinamiento de la sociedad.

\section{La exposición de Berlín Das Sowjetparadies (El Paraíso Soviético), 1942}

\subsection{Contexto histórico}

El año 1942 señaló una fecha de gran relevancia en el plano ideológico del Tercer Reich por diversas razones. En mayo, en el centro de Berlín, tuvo lugar la más elaborada, intencionada y compleja exposición anticomunista de la Alemania nazi. Un simultáneo juego de imágenes y mensajes del más acentuado odio contra todo aquel elemento relacionado con el bolchevismo. Aunque la decisión de su celebración se produjo muchos meses antes, su inauguración se enmarcó en un contexto político y militar muy preciso que determinó algunos de sus caracteres y objetivos. Goebbels, ante la creciente paralización de la Wehrmacht en el frente oriental ${ }^{23}$, instaló en su propaganda el pesimismo ${ }^{24}$, que no buscaba otra cosa que la adhesión plena y un mayor apoyo de todas las esferas sociales del país a las decisiones de su Führer. Diferentes periódicos empezaron a publicar las atrocidades y terribles experiencias experimentadas por los soldados germanos en suelo soviético ${ }^{25}$. En muchos de los informes y cartas que escribían a sus familiares se señalaba que los campesinos rusos vivían en condiciones infrahumanas, "vestidos con trapos y sin lavar» ${ }^{26}$. Esta exposición, como veremos, puede situarse en esta nueva línea ideológica. Además, semanas antes de su puesta en marcha, se convocó el Reichstag (26 de abril) para analizar la situación interior y exterior del país. Algunas de sus conclusiones, como ahora expondremos, influirían en su puesta a punto. En la reunión preparatoria entre Hitler y Goebbels, el primero recibió informes en los que se detallaba la situación de hambre y episodios de canibalismo en el ejército y la población soviética. Pero si por algo fue conocida la histórica sesión del Reichstag de abril de 1942 (la última que se

\footnotetext{
23 Podemos nombrar, por ejemplo, el sitio de Leningrado o la batalla de Moscú, pese a los puntuales éxitos en la Segunda Batalla de Jarkov o el fin del asedio de Sebastopol.

24 Durante la Guerra Civil está técnica estuvo muy presente a la hora de analizar la evolución del bando franquista.

${ }^{25}$ Sobre este tema véase KALLIS, Aristotle A., Nazi Propaganda and the Second World War, New York, Palgrave Macmillan, 2005. Véase en especial pp. 121-129.

${ }_{26}$ STENZEL, Thilo, Das Rußlandbild des Kleinen Mannes”. Gesellschaftliche Prägung und Fremdwahrnehrmung in Feldpostbriefen aus dem Ostfeldzug (1941-1944/45), München, Osteuropa-Institut, 1998.
} 
celebraría en el Tercer Reich), es porque se ampliaron -aún más- los poderes del Führer. Este tipo de medidas no distrajeron una de las principales preocupaciones del pueblo alemán: la desmoralización. La rápida victoria pregonada por el Estado en el verano de 1941 no se había producido y, como informaban los servicios de información del Partido, "cuanta más conciencia se tenga en Alemania de la crudeza y la dureza de la lucha en el Este, más fuerte se hace el deseo de que se acabe..." ${ }^{27}$. Con la intencionalidad de aunar voluntades contra el adversario e intensificar los apoyos para la campaña del invierno que se avecinaba, se multiplicaron las iniciativas dirigidas a denigrar a los comunistas y a potenciar la necesidad de lograr la máxima unidad popular para acabar definitivamente con el bolchevismo. En esta senda se encontraba la mencionada exposición y películas como GPU, que a pesar de su carácter de ficción se presentaba como poco menos que un documental sobre las temidas actividades de la policía política soviética ${ }^{28}$.

De igual forma es imprescindible mencionar la Directiva para la Propaganda de Acción Antibolchevique (Anweisung für antibolshewistische Propaganda-Aktion) de febrero de 1943, justo después de la derrota en Stalingrado. Aunque posterior en el tiempo a la exposición a la que nos referimos, algunos de los principios sobre los que profundizaba ya habían sido ensayados en Berlín en la primavera del año anterior. Goebbels, tal y como había comentado tras la campaña de invierno, quería hacer entender al pueblo, y en especial a los medios de comunicación del país, que la guerra se encontraba en una fase decisiva. Era imprescindible que la propaganda estuviese a la altura de las nuevas realidades. Mediante esta directriz, la Reichspropagandaleitung acentuó, aún más, el tono anticomunista que tenía que prevalecer en la corriente de pensamiento nazi. Bajo el lema "Victoria o caos bolchevique" se puso la atención en los siguientes aspectos. Primero, el combate que se desarrollaba en el Este de Europa no era una lucha contra el paneslavismo ni contra la unidad política y nacional de Rusia sino frente a la «idea judía destructiva que encarnaba el bolchevismo», que se traduciría para el futuro del continente en «inmensa miseria y la destrucción completa de todos los valores culturales». Segundo, «nuestra lucha contra el bolchevismo es una guerra defensiva”, que velaba por la supervivencia de Alemania y del resto de naciones “de bien”. En relación con este punto, se encontraba el argumento de que el hipotético triunfo del bolchevismo ocasionaría para Alemania la más profunda ruina económica. Este fue uno de los temas estrella de la exposición El Paraíso Soviético, que seguía al pie de la letra uno de los enunciados básicos de este guión propagandístico y que era

27 KERSHAW, Ian, op. cit., pp. 499-502.

${ }^{28}$ ESPAÑA, Rafael de, El cine de Goebbels, Barcelona, Ariel, 2002, pp. 134-135. 
vital aproximar a los ojos occidentales: «la miserable existencia de millones de personas que trabajaban en la Unión Soviética, el despiadado sistema de trabajo obligatorio y la insostenible situación en las fábricas comunistas». Para intensificar el sentido negativo de estas descripciones había que posicionarlas frente a su polo opuesto, el "muro de protección" creado por Hitler, que gracias la Wehrmacht se constituía como la "espada" que cercenaría de raíz los tentáculos del bolchevismo ${ }^{29}$.

Para reforzar esta directriz, y con la pretensión de aumentar todavía más el temor germano a los rusos y el comunismo, en marzo de 1943 se publicó el folleto Bolschewismus: was Heiß das in Wirklichkeit? (Bolchevización: ¿qué significa eso en realidad?).

\subsection{El concepto de "Paraíso Soviético" en la propaganda nazi}

Durante la Primera Guerra Mundial abundaron los testimonios de soldados de cada uno de los dos bandos en litigio sobre los crímenes y atrocidades que supuestamente perpetraban sus adversarios ${ }^{30}$. En la literatura británica aparecieron relatos en los que los alemanes eran considerados como simples "seres bárbaros contrarios a la idea de progreso espiritual" ${ }^{3}$. De un tono más agresivo fueron las cartas que remitieron los combatientes de las diferentes naciones, las cuales se emplearon para crear una imagen sádica y brutal del contrario. En el caso germano, la mayoría de esfuerzos se dirigieron al enemigo ruso. Aparecieron narraciones plenas de descripciones de actos salvajes: «los niños de la escuela tenían los dedos cortados, un oficial encontró a su mujer e hijo clavados en una mesa...». Se reservaba hueco también a los retratos de la "miserable y atrasada" vida de millones de campesinos en el imperio del comunismo ${ }^{32}$. Este fue el punto de partida de un género de literatura y propaganda, explotado hasta la saciedad por el nazismo desde sus orígenes, en el que de forma constante se nos ofrecía un cuadro muy negativo del día a día en la Rusia soviética así como de las teóricas torturas y asesinatos que allí tenían lugar. En esta senda se incluían los relatos de testigos presenciales de estos desmanes, como los del trabajador Franz Pakosch, huido del “infierno soviético". Sus crónicas fueron publicadas en el diario berlinés Vorwäts,

29 Bundesarchiv, Berlín (NSD 12/74). Se encuentra recogido en German Propaganda Archive. URL: < http://www.calvin.edu/academic/cas/gpa/bolshevist.htm > [consultado el 31 de marzo del 2014].

30 Podemos destacar, entre otros, los trabajos de HORNE, John, KRAMER, Alan, German Atrocities, 1914: A History of Denial, New Haven, Yale University Press, 2001, pp. 175-225; BECKER, Jean Jacques, Guerre et cultures, 1914-1918, Paris, Armand Colin, 1994.

${ }^{31}$ BUITENHUIS, Peter, The Great War of Words. Literature as Propaganda, 1914-1918 and alter, London, Batsford Ltd, 1987, p. 14.

$3^{2}$ MORGAN READ, James, Atrocity Propaganda, 1914-1918, New York, Arno Press, 1972. 
materializándose poco después en un polémico libro en el que Georg Schmidt recopiló sus vivencias 33 . Varios años antes, bajo el nombre de Robert Nilostonski se aproximaba al lector alemán a las más sórdidas torturas practicadas en las checas comunistas. Una de ellas consistía en colocar en una jaula de metal (sin base) al rojo vivo una rata sobre el estomago del preso, con el objetivo de que el roedor se viese obligado a abrir un agujero en la barriga de la víctima en su intento de escapar al calor abrasador del hierro34. Los testimonios del general ruso Avalov, decidido combatiente contra los bolcheviques; los del llamado "Dr. Von Gregor" (pseudónimo del SS-Standartenführer ucraniano-germano, Gregor Schwartz-Bostunitsch) o del propio Rosenberg no hicieron sino reforzar esta visión y ampliarla con otros juicios igual de violentos y repugnantes a ojos de la opinión pública35.

En la década de los treinta el concepto de Paraíso Soviético, teniendo muy en cuenta el tono de irónico y de crítica con el que se empleaba, volvió a estar muy presente en la cosmovisión nacionalsocialista. Aparte de las exposiciones que recurrían a esta terminología en su encabezamiento, así como los folletos y obras ya mencionadas, la aparición del trabajo del Unterturmführer de origen tártaro y miembro del Osttürkischer Waffen-Verban der SS, Wassilij Antonow (o Vassili Antonov) supuso un punto de inflexión importante. ¿La razón? Descontando el hecho de la "credibilidad" que le otorgaba ser de origen soviético, y por tanto conocedor de primera mano de lo que narraba, su escrito no se centraba únicamente en aspectos tan escabrosos como ejecuciones o métodos de castigo de anteriores títulos. Das Sowjeparadies (1931) era una conmovedora descripción de la penosa situación en los koljós y ciudades rusas. Para reforzar esta argumentación, el texto incluía ilustraciones de Kurt Reimer que incidían en muchos de los estereotipos del judeocomunista ${ }^{36}$.

En 1931 salió a la luz la obra del jesuita Friedricht Muckermann, Der Bolschewismus Droht, donde denunciaba los ataques que sufrieron los católicos de Colonia durante la República de Weimar. Posteriormente, se convirtió en un activo

\footnotetext{
33 PAKOSCH, Franz, In Sowjetrußland, s.l., s.e., 1928.

34 NILOSTONSKI, Robert, Der Blutrausch des Bolschewismus, Berlin, Neudeutsche Verlagsund Trauhandgesellschaft, 1924.

35 BERMOND-AVALOV, Pavel, Im Kampf gegen den Bolschewismus, Hamburg, Verlag J.J. Augustin, 1925; Dr. VON GREGOR, Ein Meer von Blut: Die Wahrheit über das Bolschewistische Russland, München, 1926; ROSENBERG, Alfred, Pest in Russland! Der bolschewismus, Seine häupter, handlanger und opfer, München, 1922. Una pormenorizada descripción de este tipo de literatura en THUM, Gregor, Traumland Osten: Deutsche Bilder vom östlichen Europa im 20. Jharhundert, Leipzig, Hübert \& Göttingen, 2006.

${ }^{36}$ ANTONOW, Wassilij, Das Sowjetparadies. Querschnitt durch die russische Revolution, Berlin, Hendrich, 1931.
} 
enemigo del Tercer Reich. Pese a ello, su trabajo constituyó un ejemplo más de rechazo al modo de vida soviético.

Todos estos productos propagandísticos, de modo general de escasa calidad creativa pero no por ello menos trascendentes en su contexto histórico, tuvieron un peso considerable en la configuración de la gran exposición anticomunista de 1942. Sin embargo, las creaciones de mayor influencia sobre este acontecimiento se desarrollaron paralelamente a la puesta en marcha de la Operación Barbarroja. Nos referimos, de mayor a menor importancia, a los trabajos de Diewerge, Klug y Petmecky. Wolfgang Diewerge fue un relevante periodista, autor de la famosa obra Das Kriegsziel der Weltplutokratie. En 1941 contribuyó nuevamente a respaldar las tesis nazis con el folleto Deutsche Soldaten sehen die Sowjet-Union. Feldspostbriefe aus dem Osten (Soldados alemanes en la Unión Soviética: cartas desde el Este). La portada que lo ilustró fue realizada por el cartonista Werner Von Axster-Heudtlass, que con anterioridad se había ocupado de realizar algún otro trabajo para el Estado en la misma línea conceptual: la lucha del Tercer Reich contra el comunismo. Uno de los aspectos por los que es más trascendente este título es porque esta imagen fue la misma que se empleó más adelante para promocionar la exposición Das Sowjeparadies. Como observará el lector en ambas ilustraciones, era resaltable el contraste entre la pobreza de unos personajes anónimos (pintados en blanco y negro para dar mayor realismo), que se podían identificar con un trabajador industrial y una ama de casa, con ropa roída, sosteniendo un niño en sus brazos, con el cuerpo desnudo, esquelético; frente a un poderoso tanque, arropado por un fondo de color rojo, símbolo universal del bolchevismo. Frente a la opulencia tecnológica, impulsada por el régimen estalinista, la población del Este sobrevivía en el umbral de la inanición, como lo probaban los rasgos demacrados de sus habitantes así como sus rudimentarias viviendas. Los testimonios privilegiados de los soldados germanos contenidos en el folleto no harían sino dar más pruebas de este simbolismo visual ideado por Axster-Heudtlass. 

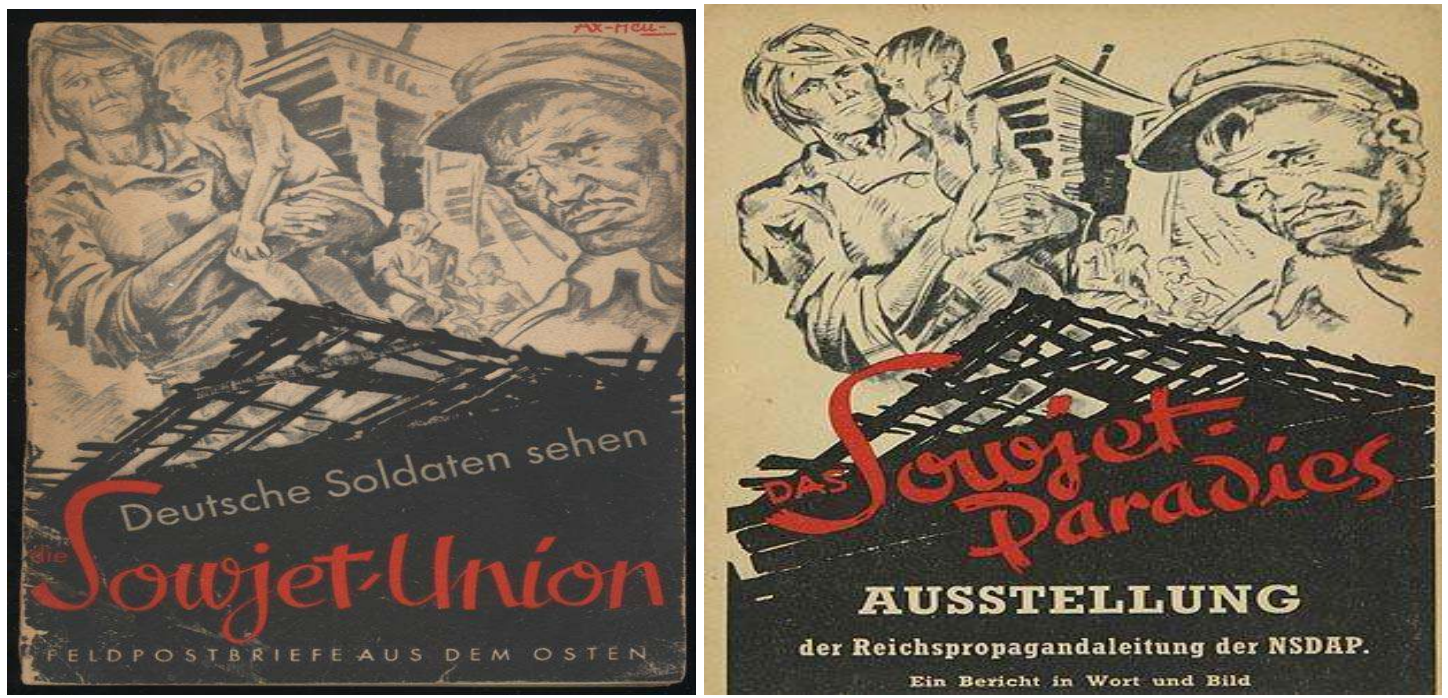

Figg. 3, 4. Dibujo de Axster-Heudtlass para el folleto de Diewerge. A la derecha cartel promocional de la exposición Das Sowjetparadies (una copia exacta de la anterior).

En ellos no se perdía ocasión de criticar "el paraíso del trabajador" y a los judíos como artífices ocultos del advenimiento del bolchevismo a escala mundial. En el relato del teniente Otto Deisenroth se describía así la ruina material del país:

Escribo esta carta de la desolación de un pueblo de Ucrania, a $40 \mathrm{~km}$ de Kiev, que esperamos capturar en pocos días. La fructífera tierra de Ucrania está a nuestro alrededor, pero 20 años de mala administración bolchevique han traído la ruina. La pobreza, la miseria, y la inmundicia que hemos visto y experimentado en las últimas semanas es indescriptible. Todo lo que se lee en los periódicos y libros palidece frente a la terrible realidad. Nuestros ojos miran en vano alguna señal de construcción, una huella de progreso, de un poco de cultura. Anhelamos la vista de una casa limpia, una calle ordenada, unos jardines, algunos árboles...

Y sobre sus viviendas se escribían aún cosas peores:

La gente de aquí no sabe nada de la luz eléctrica, la radio, los periódicos, etc. No se puede llamar a donde ellos viven casas. Solo hay chozas con techos de paja podridos. Esto es lo que la gente llama el paraíso soviético.

También se reflejaban las torturas practicadas, detrás de las cuales "siempre" estaba el judío: «vi las prisiones en Lemberg, y vi cosas que me impactaron profundamente. Había hombres con orejas y narices cortadas. Había niños vivos 
clavados a la pared de manos y pies...»37. Con estas repulsivas y brutales narraciones, no se pretendía otra cosa que, a ojos de la población alemana, presentar un ambiente infernal en el interior de la URSS que justificase la invasión de la Wehrmacht en aras de su liberación. Por terribles que nos parezcan estos relatos -la mayoría, siguiendo la regla de la exageración y la desfiguración propuesta por Goebbels- en multitud de ocasiones plasmaban episodios de barbarie reales, pero lo que hay que apuntar es que no fueron patrimonio exclusivo ruso, pues los nazis fueron alumnos y maestros aventajados en este tipo de prácticas ${ }^{38}$.

Seguidamente hay que mencionar el folleto Die großte Sklaverei der Weltgeschichte (La esclavitud más grande de la historia del mundo), prologada por Karl Neuscheler (antiguo corresponsal en Moscú del Völkischer Beobachter y experto en filología eslava), que reproducían el relato de Kajetan Klug. Líder de la Liga de Defensa Marxista de Linz, Klug huyó de Austria tras el fracaso de la insurrección de febrero de 1934. Tras pasar por Checoslovaquia se instaló en la capital rusa, donde se hizo miembro del Partido Comunista y se encargó de la dirección de los emigrantes austriacos. Pero pronto se dio cuenta - como se explicaba en la introducción - de la pobreza de los trabajadores y campesinos. Cuando criticó abiertamente estas condiciones, se le acusó de espionaje. Fue arrestado, torturado y absuelto, y finalmente condenado sin pruebas a cinco años de trabajos forzados en Asia Central. Poco antes de la contienda mundial huyó del país y juntó al personal diplomático alemán consiguió llegar hasta Berlín, donde plasmó toda esta odisea con la ayuda de la maquinaria propagandística del Tercer Reich. Algunas de las imágenes que se incluyeron, como “mapa sobre los campos de trabajo forzados en la URSS" (p. 21) aparecieron a posteriori en la guía que se editó con motivo de la exposición El Paraíso Soviético. Es más, diferentes ilustraciones que recreaban las cabañas e instalaciones de estos centros de reclusión fueron reproducidos en forma de miniaturas y maquetas en ese mismo evento.

Otra gran influencia provino de los trabajos de la abogada Adelheid Petmecky, que en sus producciones de 1941, Das Rote Kinderparadies y Bolschewistisches

\footnotetext{
37 DIEWERGE, Wolfgang, Deutsche Soldaten sehen die Sowjet-Union. Feldpostbriefe aus dem Osten, Berlin, Wilhelm Limpert-Verlag, 1941.

URL: < www.calvin.edu/academic/cas/gpa/feldpost.htm > [consultado el 31 de marzo de 2014]. 38 Sirva de ejemplo el relato de un veterinario polaco sobre las "misiones" de las SSEinsatzgruppen a finales de 1941: «Recuerdo también que durante el exterminio de los judíos en el bosque, uno de los hombres de la Gestapo arrancó un niño pequeño de manos de su madre y le golpeó la cabeza contra el borde del coche ante su vista. Cuando la madre se puso a gritar, la golpeó con el cuerpo del niño de tal manera que la cabeza de éste dio contra la boca de la madre, donde se le quedó enganchado parte del tejido cerebral del hijo. A continuación, sacó algo del coche - cal o cemento rápido - y le selló la boca». RHODES, Richard, op. cit., p. 319.
} 
Frauenschiksal, realizó unas muy particulares descripciones y caricaturas sobre las mujeres y los niños soviéticos, las cuales tuvieron un amplio reflejo en los fotomontajes que decoraron cada una de las salas de la exposición que se celebraría en Berlín al año siguiente.
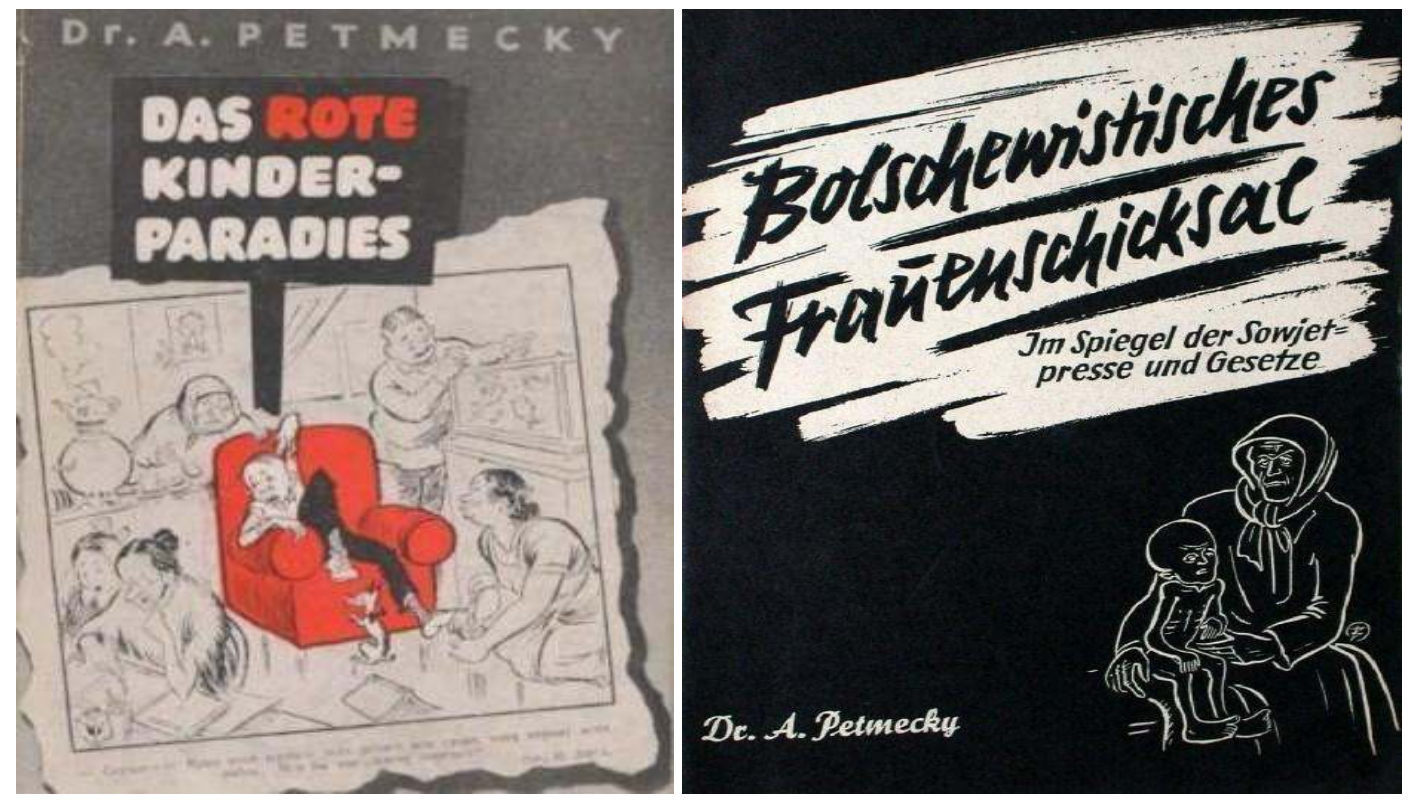

Figg. 5,6. Portadas con caricaturas incluidas en las obras de Adelheid Petmecky. Algunas de las ilustraciones que decorarán las salas de la exposición Das Sowjetparadies copiarán este estilo.

En todas estas publicaciones se encontraban perfectamente esbozadas y definidas las líneas maestras que vertebrarán la exposición El Paraíso Soviético: el atrasado modo vida en la URSS, sus viviendas y poblados, los campos de concentración, las penurias y limitaciones propias del comunismo, la responsabilidad judía y el contraste con su opulenta forma de vida. Conceptos todos ellos opuestos a la Volkgemeinschatf defendida por el Tercer Reich.

\subsection{Despliegue de la exposición en la capital del Reich}

En mayo de 1942, después de su peregrinaje por Viena ${ }^{39}$ y Praga $^{40}$, llegaba la exposición El Paraíso Soviético a la capital del Reich. El sitio escogido para su

39 BURGSTALER, Rosemarie, «Bilder nicht nur im Kompf» (20 de diciembre de 2013). URL:

< http://diepresse.com/home/spectrum/zeichenderzeit/1510215/Bilder-nicht-nur-im-Kopf > [consultado el 31 de marzo de 2014].

$4^{0}$ Sobre el desarrollo de esta exposición en Praga, véase URL:

< http://nassmer.blogspot.com.es/2012/o3/vystava-sovetsky-raj-v-praze-1942.html >

[consultado el 31 de marzo de 2014]. 
celebración no podía ser más monumental y con mayor carga ideológica: el Lustgarten ("Jardín de la Alegría”). Se ubicaba en el centro de la ciudad, junto al Stadtchoss Berliner y la catedral. Durante la república de Weimar se había utilizado con frecuencia para manifestaciones políticas y, a partir de 1933, el NSDAP lo escogió como tribuna preferente para sus discursos y eventos públicos, como las fiestas del $1^{\circ}$ de mayo o la inauguración de los Juegos Olímpicos de 1936. Este gran acto propagandístico se desplegó sobre una superficie de 9000 metros cuadrados, que formaba una gigantesca "ciudad de carpas" que albergaban en su interior las "pruebas irrefutables" del modo de vida que sufría la población en la Unión Soviética ${ }^{41}$.

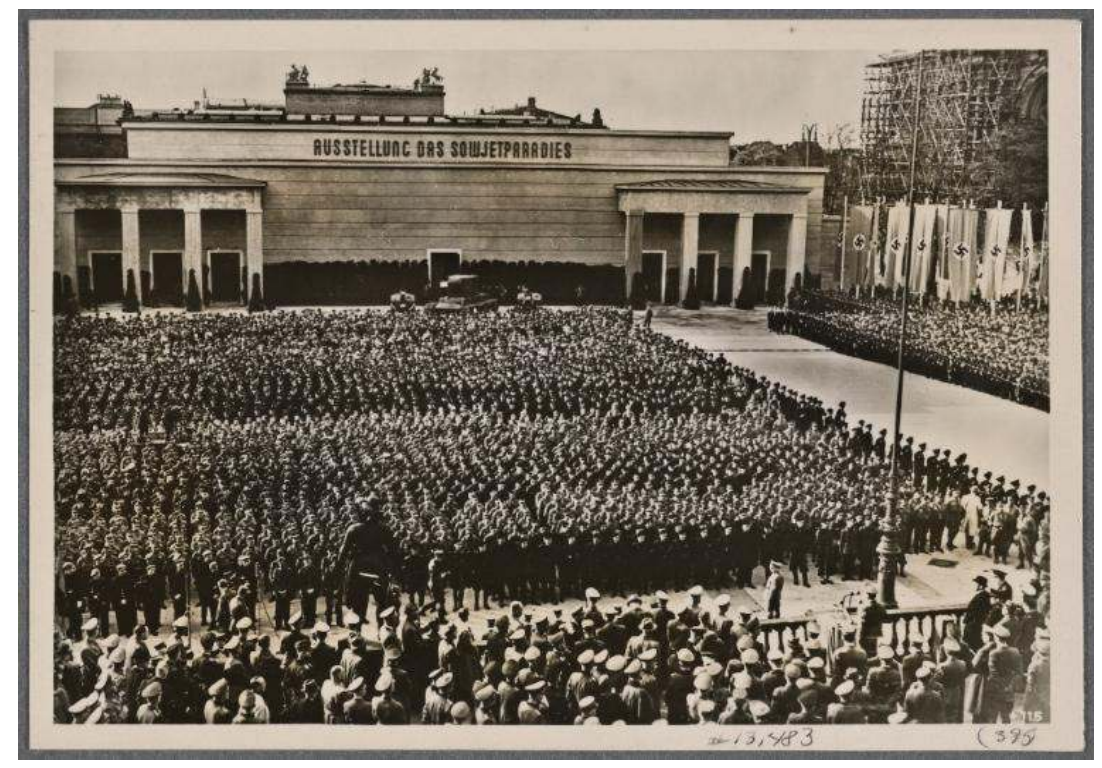

Fig. 7. La plaza del Lustgarten de Berlin el día que se inauguraba la exposición (Fuente: Archivo personal del autor)

Para darle la mayor resonancia internacional a este evento se invitó a su inauguración a miembros del Partido Fascista Italiano y de Falange Española, así como representantes de la División Azul ${ }^{42}$. En la prensa española se publicaron diversas fotografías en las que aparecían miembros de dicho cuerpo frente a la catedral así como

\footnotetext{
${ }^{41}$ En los medios periodísticos españoles se multiplicaron las referencias a este tema desde la invasión alemana de la URSS. Baste como ejemplo la noticia «Ha llegado a Madrid una expedición de niños españoles procedentes de Rusia", que contenía sentencias tales como "todas las versiones de estos niños que, por otra parte, vivieron en distintos lugares de Rusia, coinciden en descubrir la vida en el Paraíso comunista con estas tres palabras: hambre, horror y miseria [...]» La Vanguardia Española, 13 de diciembre de 1942. Ya en los años treinta, se podía leer: «casi todas las obreras tienen tres y cuatro, y muchas veces cinco y seis bocas que mantener. Las condiciones de la vivienda son intolerables. De cuarenta y dos obreras sometidas a encuesta, cinco no pueden mandar a sus hijos a la escuela por falta de medios materiales; once no tienen zapatos ni ropa de abrigo ni para ellas ni para sus chicos; catorce no siempre pueden comer un plato caliente por día; doce son analfabetas [...]». «El mito de Rusia (la mujer)», in La Victoria. Semanario católico de Béjar, 25 de mayo 1935.

42 Véanse las referencias aparecidas en $A B C$, los días 19 y 23 de mayo de 1942.
} 
en otros actos en su honor durante ese mes de mayo. Junto a las mismas se mostró en primera plana al Secretario de Estado del Ministerio de Propaganda, Leopold Gutterer, que en el discurso de apertura hacía un elogio a la resistencia del pueblo alemán frente al comunismo, tanto en la presente guerra como en el pasado 33 .

Los organizadores intentaron de la manera más realista posible, mediante dioramas, diagramas, paneles, fotomontajes, fotografías y material de guerra, aproximar al ciudadano de a pie alemán a la "realidad" económica, política, social y racial de la URSS. Se situó la lupa sobre un determinado espacio geográfico: Minsk. Al comienzo de la guerra había casi dos millones de judíos entre Bielorrusia y Ucrania. La capital bielorrusa había sido invadida (28 de junio de 1941) al poco de iniciarse la Operación Barbarroja. Los nazis convirtieron la ciudad en el centro administrativo del Reichskommisariat Ostland, bajo la supervisión del Oberpräsident de SchleswigHolstein, Hinrich Lohse44. Desde un primer momento se reprimió duramente a la población. El 20 de julio se ordenó el establecimiento de un ghetto judío (cien mil habitantes), en un área que comprendía 34 calles, así como el cementerio. El ghetto estaba rodeado de un muro de ladrillo y alambradas, así como torres de vigilancia y guardias que patrullaban el perímetro. Se estableció un promedio de $1,5 \mathrm{~m}^{2}$ por habitante, sin tener en cuenta el espacio necesario para los niños. Miles de habitantes del ghetto vivían en las ruinas de las casas destruidas, sin suelos o ventanas. En noviembre de 1941 un segundo ghetto fue establecido para judíos deportados de Europa occidental. Eran en su mayoría de Alemania y el Protectorado de Bohemia y Moravia45. Fue este apocalíptico paisaje, creado por la fuerza por las autoridades nazis, el que se decidió exportar para su observación dentro del Reich, como si los judíos que allí habitaban fuesen los responsables del caos y deficiencias que les rodeaban.

Una de las primeras salas que encontraba el visitante era "Der Reichtum des Ostens" (La Riqueza de Oriente), compuesta por grandes dioramas de tipo abierto, es decir, que podían ser observados desde diferentes puntos de vista ${ }^{46}$, sobre la inmensidad del paisaje del Este, que se caracterizaba por campos en medio de bosques gigantescos e interminables llanuras. También se reservaba hueco en las paredes para la colocación de cinco grandes mapas temáticos (diagramas) sobre los cultivos en suelo

43 KIVELITZ, Christoph, Die Propagandaausstellung in europäischen Diktaturen. Konfrontation und vergleich: Nationalsozialismus in Deutschland, Faschismus in Italien und die UdSSR der Stalinzeit, Bochum, Verlag, 1999, pp. 228-229.

44 RHODES, Richard, op. cit., p. 193.

45 Información detallada sobre este asunto en EPSTEIN, Barbara, The Minsk Ghetto, 1941-1943: Jewish resistance and Soviet internationalism, California, University of California Press, 2008. ${ }^{46}$ Un diorama es un tipo de maqueta que muestra figuras humanas, animales o incluso seres imaginarios como punto final de su composición, presentados dentro de un entorno y con el propósito de representar una escena. 
ruso, los recursos naturales, la distribución de la población, la red de transportes y las nacionalidades que conformaban la URSS. Todo estaba enfocado a una idea muy clara: se trataba de un país muy rico, excelente para el pleno desarrollo económico de la población47. Entonces, ¿por qué el pueblo sólo conocía la pobreza? Para obtener respuesta había que esperar, aún, a conocer otras salas. La segunda de ellas era "Die germanische Durchdringung des Ostens" (La penetración germánica en el Este). A través de murales de gran longitud, obra de los artistas Karl Kemetter (pintor vienés de retratos), Kitt Ferdinand (Profesor en la Academia de la Mujer de Viena) y Ernst Holzinger (director del Museo de Frankfurt), se realizaba un particular repaso histórico sobre el proceso de colonización germana hacia el Volga y los ataques que Europa occidental sufrió desde Oriente, con especial atención a los de los hunos y los mongoles. Frente a estas civilizaciones "inferiores”, portadoras de caos y destrucción, los reinos de origen ario habían portado la prosperidad a sus vecinos. Era el caso, por ejemplo, del mítico rey Rurik, que procedente del Ladoga gobernó en Kiev en el siglo XVI. Otro mural mostraba a un grupo de caballeros teutones, comerciantes y campesinos durante la Alta Edad Media en su travesía hacia una nueva tierra en la que plantaron "orden y cultura”. Estas cualidades, como se plasmaba en un diagrama, se truncó debido a la eclosión del marxismo y el anarquismo en Europa entre 1848 y 1918; y del bolchevismo entre esa fecha y 1942. De esta manera, se marcaban mediante una llama sobre los diferentes países del continente los principales acontecimientos detrás de los cuales se encontraban estas "peligrosas" ideologías, como las revoluciones burguesas de 1848, la Comuna de París de 1871, la Revolución de Octubre de 1917, la Semana Trágica de Barcelona, la Revolución de Asturias, la Guerra Civil española... Para reafirmar estos sucesos se confeccionó un mural titulado "La Revolución bolchevique, la gran catástrofe de la Historia”, bajo el cual tres grandes pantallas recogían pequeñas filmaciones sobre los mismos. Esta sala, en definitiva, pretendía equiparar el carácter "civilizador" de las colonizaciones medievales con la labor de "liberación" que llevaba a cabo la Wehrmacht en suelo soviético desde el verano de 1941, víctima desde el siglo XIX de las ideologías atacadas en las obras visuales nazis ${ }^{48}$.

A continuación venía "Die Scheinfassade des Bolschewismus" (La Fachada del Bolchevismo), en la que se incidía en la falsa idea de que la URSS era un "paraíso de los agricultores y los trabajadores”. Para desmontar esta argumentación, los numerosos fotomontajes de este espacio explicaban que "detrás de la monumentalidad de los

47 Das Sowjet-Paradies. Ausstellung der Reichspropagandaleitung der NSDAP. Ein Bericht in Wort und Bild, Berlin, Zentralverlag der NSDAP, 1942, pp. 5-7.

48 Ibidem, pp. 8-17. 
edificios gubernamentales se ocultaban casas en ruinas de los obreros". También se explicaba que frente al enorme desarrollo armamentístico del que se enorgullecía la propaganda soviética, el pueblo estaba "hambriento y harapiento". Para ello se colocaba en una de las paredes un diagrama sobre el incremento de la producción de aviones, tanques y artillería del Ejército Rojo desde 1927 hasta 1941 en contraposición con la fotografía de un adolescente sin calzado, con unas mantas mugrientas y roídas como única protección frente al duro invierno siberiano, en una calle repleta de edificios en ruinas. En otro rincón aparecían varias viñetas en orden lineal que analizaban cómo, a medida que se asentaba el régimen de Stalin, empeoran las condiciones en las viviendas de los trabajadores, que si bien en 1916 albergaban a una media de tres personas (en 16 $\mathrm{m}^{2}$ ) en 1939 su número se elevaba a la desorbitada cifra de seis.

Toda la sala estaba presidida por una enorme escultura decapitada de Lenin, símbolo de la sin razón del bolchevismo y de sus obras: «asesinatos, incendios, hambre, guerra...»49.
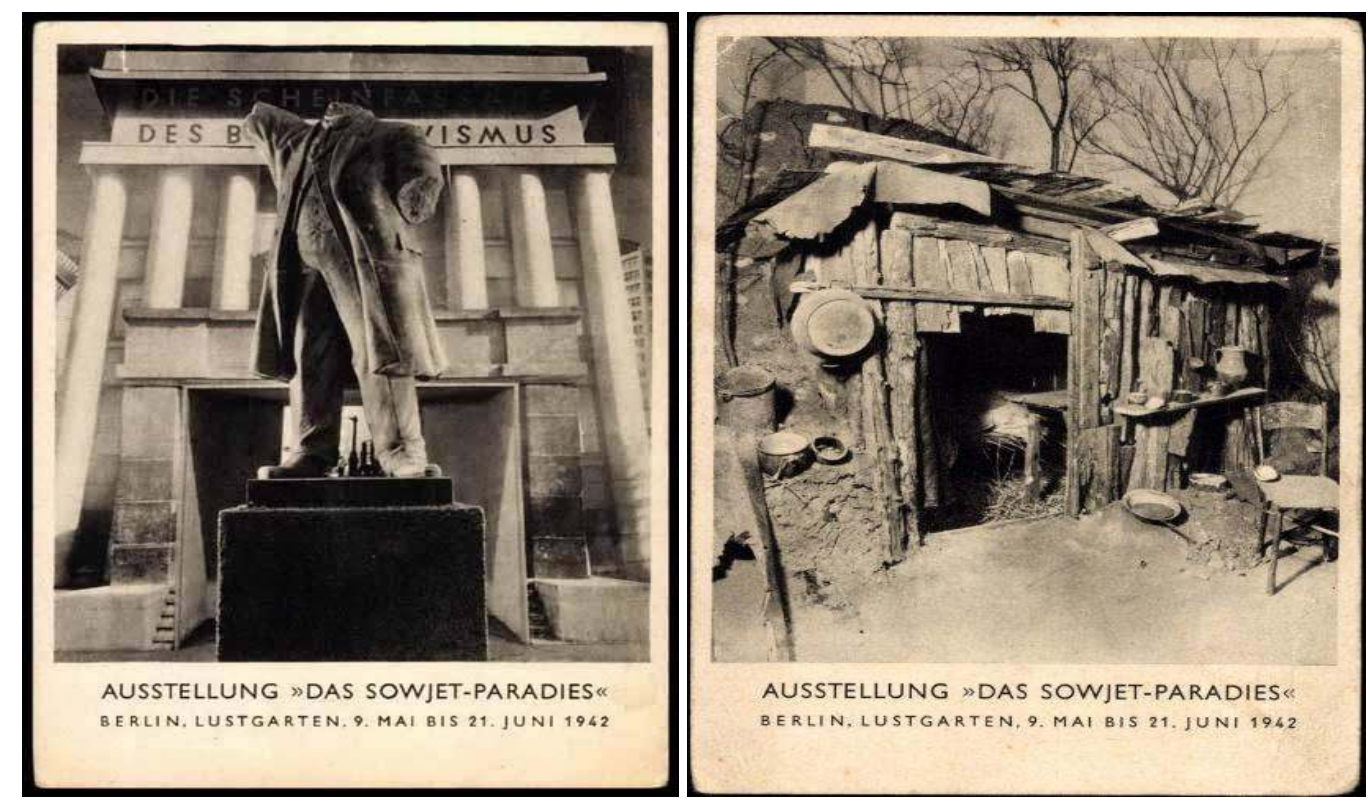

Figg. 8,9. Diferentes postales alemanes con imágenes tomadas de la Exposición El Paraíso Soviético.

(Fuente: Archivo personal del autor)

Pruebas materiales del peligro real que constituía el bolchevismo para el futuro de Europa se contenían en la sala "Die Sowjet-Armee" (El Ejército Soviético), plena de cañones, ametralladoras, uniformes... así como mapas donde se relataban sus movimientos en la actual contienda mundial. Era muy llamativa la figura del "perromina”, acompañado de una leyenda que decía que «estos desgraciados animales son entrenados por los bolcheviques para que puedan obtener su alimento exclusivamente

49 Ibidem, pp. 20-21. 
de un tanque; por lo tanto, los animales hambrientos se abalanzan sobre los carros de combate enemigos en la fe que saciarán su hambre. Los perros llevan dos minas en la parte posterior. Cuando tocan uno de ellos con una varilla que llevan sobre el cuerpo se desencadena una explosión»50. Esta circunstancia fue explotada por la propaganda alemana para explicar que estos animales tenían más valor que los soldados rusos.

$\mathrm{El}$ tema de las armas y el material bélico ruso estuvo muy presente en los actos propagandísticos nazis ${ }^{51}$. En marzo de 1943 se celebró en el Berliner Zeughaus (Antiguo arsenal de la capital) la exposición Sowjetischer Beutewaffen, que reunía numeroso material de guerra del enemigo. La "barbarie" de estos soldados incivilizados - según la terminología empleada” - contrastaba con el honor y valentía del alemán, que incluso en el frente de combate más infernal era capaz de realizar excelentes grabados y dibujos que dieron lugar a exposiciones como Tag der Wehrmacht, Die Kunst der Front (ambas de 1941) y Kunst der Front (1942).

$\mathrm{El}$ ataque a la organización social en la URSS fue tratado en el cuarto "Klassen im klassenlosen Staat" (Clases en el Estado sin clases). Diferentes figuras a tamaño real sobre podios analizaban el posicionamiento de los diferentes grupos. En la parte más elevada estaban los líderes judíos, pasando por los obreros, los campesinos y los trabajadores forzados. Fotografías de ancianos decrépitos (bajo el título "la vida sin sentido) y de hogares deprimentes completaban el cuadro ${ }^{52}$.

En otra sala se describían las torturas practicadas por la GPU y se ponía rostro a uno de sus principales líderes en Bielorrusia, el Comisario Rajewsky, responsable como se explicaba en la guía de la exposición- del asesinato de 200.000 personas a lo largo de cinco años. Se incluía el relato de Kajetan Klug, al que ya tratamos en páginas anteriores, sobre su vida en un campo de trabajos forzoso y fotografías y recreaciones de los castigos que se practicaban en las checas53, como "el guante", donde el preso metía la mano en agua hirviendo para después despellejarla fácilmente54. Después se reservaban otros habitáculos al estudio de la "la difícil situación de los agricultores

\footnotetext{
50 Ibidem, p. 25.

${ }^{1}$ Cabe recordar que, en plena Guerra Civil, el bando franquista celebró una exposición muy similar, en este caso centrada en las armas del Ejército republicano, titulada Exposición de "material cogido" al enemigo, celebrada en San Sebastian en agosto de 1938. Sobre este tema véase, BASILIO, Miriam M., Visual Propaganda, Exhibitions, and the Spanish Civil War, Aldershot, Ashgate Publishing Limited, 2013, pp. 182-191.

$5^{2}$ Ibidem, p. 26.

53 Una de estas recreaciones, donde un preso se encontraba en un espacio muy reducido comprimido por dos grandes barrotes verticales y uno horizontal, se utilizó para anunciar la exposición El Paraíso Soviético en el diario Labor, 12 de mayo de 1942. A esta imagen se la tituló "Celda de tortura de la GPU”.

54 Das Sowjet-Paradies. Ausstellung der Reichspropagandaleitung der NSDAP. Ein Bericht in Wort und Bild, Berlin, Zentralverlag der NSDAP., 1942, p. 33.
} 
rusos en las granjas colectivas" y "a la vida y al trabajo en el Paraíso Soviético”, que recreaban de manera fidedigna las calles, viviendas y granjas de Minsk55.
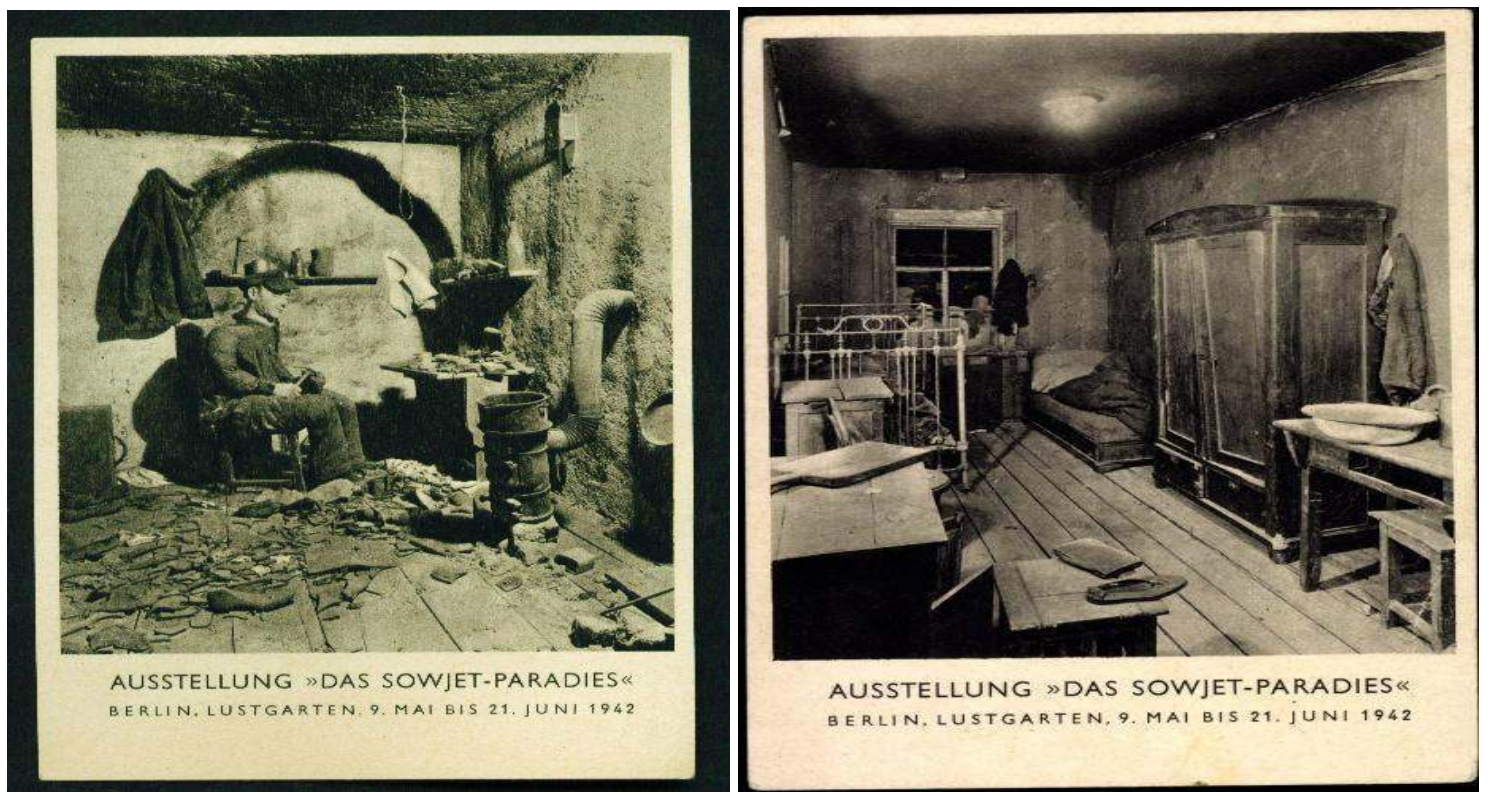

Figg. 10, 11. Recreación de las condiciones de trabajo y vida en El Paraíso Soviético. (Fuente: Archivo personal del autor)

La parte final de la exposición era un llamamiento al optimismo. Bajo el título "Europa toma parte", se remarcaba que aunque en el Paraíso soviético solo se conocía el hambre, la miseria y la necesidad; Alemania y sus aliados estaban en continua lucha para acabar de una vez por todas con la amenaza judeobolchevique en Europa ${ }^{56}$. Al igual que eventos anteriores, se proyectó un corto documental (doce minutos) que incidía en todos los elementos recogidos en las diferentes salas. Fue producido por la Sección de Audiovisuales del Reichpropagandaleitung y dirigido por Friedrich Albat.

Cuando se cerró este gran montaje propagandístico en junio más de un millón de visitantes había contemplado esta exposición, que al poco tiempo también visitó Luxemburgo y Noruega, donde contó con la participación del propio MinistroPresidente, Vidkun-Quisling.

Todo este gigantesco mecanismo propagandístico y el éxito que alcanzó pudieron irse al traste el 18 de mayo de 1942, cuando un grupo de judíos comunistas liderados por Herbert Baum intentaron incendiar las carpas mediante bombas incendiarias. El día anterior, otro grupo opositor, Roten Kapelle -liderado por Harro Schulze y Fritz Thiel- habían arrojado por el centro de Berlín cientos de folletos con la leyenda: "Exposición permanente / El Paraíso Nazi / Guerra/ Mentira / Hambre / Gestapo /

55 Ibidem, pp. 34-47.

${ }^{6}$ Ibidem, p. 48. 
¿Hasta cuando?”. La organización de Baum había desarrollado, desde principios de 1941, actividades clandestinas consistentes en la preparación y distribución de folletos de propaganda contra la guerra. Con su sabotaje quería demostrar al mundo que no todos los ciudadanos comulgaban con las ideas de Hitler. Las cinco bombas que instalaron provocaron un pequeño incendio que fue rápidamente sofocado por los bomberos. La prensa silenció totalmente el asunto y al día siguiente la exposición abrió sus puertas como si nada hubiese pasado. A los pocos días, los siete responsables de esta maniobra así como otros miembros de la organización de Baum fueron arrestados por la Gestapo. La mayoría de ellos fueron ejecutados a lo largo de ese año y el siguiente57. Este era, en definitiva, el Paraíso nazi.

\section{Conclusiones}

Una de las características básicas de los movimientos totalitarios es el deseo de atraer a las masas. Este ejercicio se puede lograr de diferentes maneras, mediante el adoctrinamiento ideológico (pensado para el ámbito de la política interior) y la propaganda, que -según los dictados de la filósofa Hannah Arendt- estaría dirigida al mundo exterior y a los sectores de la población más acríticos o menos propensos a las ideas del Estado totalitario58. En el Tercer Reich, como sucedió en otros regímenes de naturaleza similar como el soviético, esta propaganda era indivisible del terror y la violencia. Es más, ambas eran parte intrínseca y constitutiva de la misma. Todas las exposiciones nazis59 asimilaron una fuerte carga de violencia visual, de rechazo, de odio, fruto de un metódico y bien estudiado plan de exaltación de los valores arios frente a los enemigos políticos y raciales, que constituían un mismo ente para las élites del NSDAP. En todas estas proyecciones ideológicas y propagandísticas afloraba un sentimiento claro, el deseo de reescribir la historia según sus intereses. Si el marxismo había intentado interpretar la historia del mundo en términos de lucha de clases, el

\footnotetext{
57 Sobre este incidente véase, LINDENBERGER, Herbert, «Heroic or Foolish? The 1942 Bombing of a Nazi Anti-Soviet Exhibit», Telos, 135, 2006, pp. 127-154.

${ }^{8} \mathrm{El}$ análisis de la propaganda totalitaria en ARENDT, Hannah, Los orígenes del totalitarismo, Madrid, Alianza Editorial, 2013, pp. 474-501.

59 En este estudio nos hemos centrado únicamente en la desarrollada en Berlín en plena guerra mundial, sin embargo a lo largo de los años 30 se desplegaron gran número de ellas por todo el Reich cuyo eje temático también fue el anticomunismo y el antijudaísmo. De modo sucinto podemos nombrar, Weltfeind Nr. 1 - Der Bolschewismus (El Enemigo N. ${ }^{\circ} 1$ - El Bolchevismo), del 8 de septiembre de 1936 al 30 de mayo de 1937; la Große antibolschewistische Schau (Gran Exposición Antibolchevique), de noviembre de 1936 a enero de 1937; Bolschewismus ohne Maske (El Bolchevismo sin máscara), septiembre de 1937 a abril de 1938; Der Ewige Jude (El Judío Eterno), de noviembre de 1937 a junio de 1939. Una obra genérica básica para el estudio de todas ellas es: KIVELITZ, Christoph, op. cit.
} 
nazismo presentó al pueblo alemán como víctima de una conspiración judía responsable de los grandes males del país desde tiempo inmemorial. Toda esta literatura, así como las tesis de los más destacados ideólogos del Ministerio de Goebbels, tomaron cuerpo en las exposiciones de propaganda negativa que se impulsaron desde 1936, coincidiendo con el inicio de la Guerra Civil española. Y las clasificamos de esa manera porque los elementos que en ella defendieron, teñidos todos del color del odio, solo encontraban su razón de ser y lograban el impacto público que pretendían mediante la técnica de la confrontación y de la antitesis con todo aquello que rezumase judaísmo y bolchevismo. Para conseguirlo se recurrió a destacados ilustradores como Max Eschle, Mjölnir, Ottomar Anton o Axster-Heudtlass, que a través de grandes carteles ensalzaron la imagen de un Tercer Reich victorioso y pleno de valores frente a la decadencia y maldad de sus enemigos raciales e ideológicos. Otro mecanismo que participó en el juego de contraposición de ideas fue el de los fotomontajes, que a partir de imágenes reales convenientemente sacadas de contexto daban una impresión "real" del mundo al que era necesario combatir.

Los millones de visitantes de estas exposiciones daban cuenta de la gran aceptación social que alcanzaron la práctica totalidad de ellas, siendo un arma destacada para lograr la cohesión interna en un ambiente de guerra mundial, máxime cuando las bombas Aliadas llegaban a sus propios hogares y sufrían de primera mano el ambiente bélico. No podemos minusvalorar tampoco el importante papel que jugaron este tipo de actos públicos como mecanismo de consenso y acatación -aunque fuese de manera indirecta- de la política de exterminio total contra los judíos practicada por la Wehrmacht en los territorios ocupados. Las teorías de Athens señalaban como paso previo y necesario a la violencia física un primer estado de brutalización, en el que se incluía el adoctrinamiento violento de los ciudadanos. Como se defendió en exposiciones como El Paraíso Soviético, la población soviética ya vivía un infierno diario, solo restaba que las tropas alemanes lo liberasen del mismo, sin importar los medios. 


\section{* Los autores}

Antonio César Moreno Cantano es Doctor en Historia Contemporánea por la Universidadde Alcalá de Henares (2008). Miembro del grupo de investigación CEFID (Centre d'Estudis sobre les Èpoques Franquista i Democràtica) y GREF (Grup de Recerca sobre l'Època Franquista), adscritos a la Universidad Autónoma de Barcelona y del grupo de investigación Catolicismo y laicismo en la España del siglo XX, vinculado a la Universidad de Alcalá, y al grupoEstudios del Tiempo Presente, dirigido por el catedrático Rafael Quirosa, dela Universidad de Almería. En la actualidad trabaja como Profesor de Secundaria en el Colegio Madrigal (Loranca - Fuenlabrada -, Madrid). Ha participado en diferentes congresos nacionales e internacionales sobre la dictadura franquista y ha publicado numerosos artículos sobre la propaganda interior y exterior de la España franquista durante la Guerra Civil y la Segunda Guerra Mundial en diferentes revistas especializadas. Ha coordinado en Trea una trilogía sobre las culturas bélicas y la propaganda en España entre 1936 y 1945. Su última publicación ha sido la obra colectiva Otra Iglesia. Clero disidente durante la Segunda República y la Guerra Civil.

URL: < http://www.studistorici.com/progett/autori/\#Moreno-Cantano >

Misael Arturo López Zapico es licenciado con grado en Historia por la Universidad de Oviedo con premio fin de carrera y premio extraordinario de licenciatura y Doctor por la Universidad de Huelva con premio extraordinario de doctorado en Arte y Humanidades. Ha sido profesor asociado en las Universidades de Oviedo y Murcia y ha realizado estancias como investigador visitante en SUNY New Paltz, UMASS at Amherst, y University of Leeds. En la actualidad es Profesor-tutor del centro asociado de la UNED en Asturias.

URL: < http://www.studistorici.com/progett/autori/\#López-Zapico >

\section{Per citare questo articolo:}

MORENO CANTANO, Antonio César, LÓPEZ ZAPICO, Misael Arturo, «La gran exposición anticomunista del Tercer Reich: Das Sowjetparadies (1942)», Diacronie. Studi di Storia Contemporanea : Le esposizioni: propaganda e costruzione identitaria, 29/6/2014,

URL: < http://www.studistorici.com/2014/06/29/moreno-cantano_lopez-zapico_numero_18/ >

Diacronie Studi di Storia Contemporanea $\beta$ www.diacronie.it

Risorsa digitale indipendente a carattere storiografico. Uscita trimestrale. redazione.diacronie@hotmail.it

Comitato di redazione: Jacopo Bassi - Luca Bufarale - Elisa Grandi - Deborah Paci - Fausto Pietrancosta - Matteo Tomasoni - Luca Zuccolo

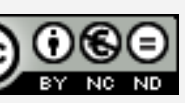

Diritti: gli articoli di Diacronie. Studi di Storia Contemporanea sono pubblicati sotto licenza Creative Commons 2.5. Possono essere riprodotti a patto di non modificarne i contenuti e di non usarli per fini commerciali. La citazione di estratti è comunque sempre autorizzata, nei limiti previsti dalla legge. 